\section{Clinical trial and 'real-world' data support switching from a bio-originator to its biosimilar}

In their correspondence, Cantini and Benucci ${ }^{1}$ voice concern regarding the recommendation of our international multidisciplinary task force on biosimilars that 'a single switch from a bio-originator to one of its biosimilars is safe and effective. ${ }^{2}$ This recommendation was based on consistent evidence from randomised controlled trials comparing biosimilars to their respective reference products in patients with rheumatologic diseases, in which subjects treated with a reference product were subsequently transitioned to treatment with its biosimilar. In all such studies that have been published to date, there has been no significant loss of efficacy or increase in the incidence of adverse events or of antidrug antibodies following such a change. This has been demonstrated not only for biosimilars of infliximab ${ }^{3-6}$ and etanercept, ${ }^{7}$ but also for biosimilars of adalimumab. ${ }^{89}$

The NOR-SWITCH study met its primary endpoint at 52 weeks, thereby demonstrating non-inferiority of changing treatment from bio-originator infliximab to biosimilar infliximab CT-P13 (infliximab-dyyb) to continued treatment with bio-originator infliximab in patients with any of the six inflammatory diseases for which infliximab is indicated who had exhibited stable disease activity over the previous 6 months. ${ }^{10}$ It is important to recognise that this prospective, double-blind, randomised controlled trial was powered to demonstrate noninferiority of changing to the biosimilar to continued treatment with the bio-originator in the aggregated population of patients with the six inflammatory diseases; it was not designed to assess non-inferiority of this treatment strategy in any individual disease. As Cantini and Benucci point out, 248 (51.6\%) of the 481 subjects enrolled in NOR-SWITCH had inflammatory bowel disease and 35 (7.3\%) had psoriasis. However, the other $198(41.2 \%)$ had an inflammatory rheumatologic disease and, although not powered to do so, this study demonstrated noninferiority of changing to biosimilar infliximab for the subgroup of patients with spondyloarthritis. Thus, the results of the NORSWITCH study support changing treatment from bio-originator to biosimilar infliximab in patients with inflammatory rheumatologic diseases.

Ample published 'real-world' experience supports the efficacy and safety of switching from bio-originator infliximab to biosimilar infliximab CT-P13 in patients with inflammatory rheumatologic diseases. Avouac and coworkers observed no change in objective disease activity measures or infliximab trough levels among 260 patients with chronic inflammatory diseases, who were maintained on bio-originator infliximab and systematically transitioned to treatment with biosimilar infliximab CT-P13, of whom 31 (11.9\%) had rheumatoid arthritis and $131(50.4 \%)$ had axial spondyloarthritis. ${ }^{11}$ After the third infusion of biosimilar infliximab CT-P13, 148 (91.4\%) of these 162 patients remained on treatment with the biosimilar; the majority of those who discontinued treatment did so because of perceived inefficacy and not because of adverse events. Germain and colleagues observed similar treatment retention rates, after a median follow-up of 120 weeks, among 50 patients with 'stable rheumatic diseases' who had transitioned from bio-originator infliximab to biosimilar infliximab CT-P13, as compared with a historical cohort of patients treated with the bio-originator. ${ }^{12}$ Benucci and collaborators reported no statistically significant differences in efficacy, safety or immunogenicity among 41 patients with spondyloarthritis who had been treated for at least 6 months with bio-originator infliximab and were changed to treatment with biosimilar infliximab CT-P13 for economic reasons. ${ }^{13}$ Nikiphorou and colleagues observed similar patientreported disease activity and symptoms after transitioning to biosimilar infliximab CT-P13, among 39 consecutive patients with inflammatory rheumatologic diseases that had been well controlled or in remission on treatment with bio-originator infliximab. ${ }^{14}$ Six $(54.5 \%)$ of the 11 patients in this cohort who discontinued biosimilar infliximab did so for subjective reasons without evidence of increased disease activity. Smaller 'realworld' observational studies also have confirmed comparable efficacy and safety of transitioning from bio-originator infliximab to biosimilar infliximab CT-P13 to that of continuing treatment with bio-originator infliximab. ${ }^{15}$

Data from registries also support the safety and efficacy of changing from a bio-originator to its biosimilar. Although the adjusted absolute retention rate after a mandated change in treatment to biosimilar infliximab CT-P13, among the 802 patients with rheumatoid arthritis, psoriatic arthritis or axial spondyloarthritis in the DANBIO registry, was slightly but statistically significantly lower than that in a historical cohort of patients treated with bio-originator infliximab, the 1-year crude retention rate $(84.1 \%)$ on biosimilar infliximab CT-P13 did not differ significantly from that on the bio-originator $(86.2 \%)$ in the historical cohort. ${ }^{16}$ Likewise, among the 1621 patients with rheumatoid arthritis, psoriatic arthritis or axial spondyloarthritis in the DANBIO registry who changed from bio-originator etanercept to biosimilar etanercept SB4, the 1 -year adjusted retention rate $(83 \%)$ was higher than that $(77 \%)$ of the 440 patients who remained on treatment with the bio-originator. ${ }^{17}$

Cantini and Benucci also suggest that our recommendation that 'multiple switching between biosimilars and their biooriginators or other biosimilars should be assessed in registries' $^{2}$ 'may be misleading for clinicians' because of 'the paucity of data from real-life and the absence of controlled trials. ${ }^{1}$ The double-blind, randomised, controlled EGALITY trial demonstrated no loss of efficacy after three switches back and forth between bio-originator etanercept and biosimilar etanercept GP2015 in patients with moderate-to-severe chronic plaque psoriasis. ${ }^{18}$ Although switching between different biosimilars and their bio-originators has not yet been studied in a clinical trial, available clinical trial and 'real-world' data do not suggest that this will result in significant loss of efficacy or increase in adverse events or immunogenicity. Bio-originators have undergone multiple manufacturing process changes after marketing approval, ${ }^{19}$ which have brought about batch-to-batch variation in molecular characteristics and occasionally in functional properties. ${ }^{2021}$ Batches of a bio-originator sourced in the European Union may differ in various product attributes even from batches of the same drug sourced in the USA. ${ }^{22}$ Thus, for years, patients already have been switched unwittingly between variants of the same bio-originator that may differ as much or as little as do biosimilars from their reference products and from one another. Careful postmarketing pharmacovigilance should be conducted for all biopharmaceuticals, both bio-originators and biosimilars, and the information obtained through this process should be maintained in registries. These accumulated data will provide additional evidence to inform the practice of switching among multiple biosimilars and their reference products.

Jonathan Kay $\odot,{ }^{1}$ Thomas Dörner, ${ }^{2}$ Paul Emery $\odot{ }^{3}{ }^{3}$ Tore K Kvien, ${ }^{4}$ Ferdinand C Breedveld ${ }^{5}$ 
${ }^{1}$ Division of Rheumatology, Department of Medicine, UMass Memorial Medical Center and University of Massachusetts Medical School, Worcester, Massachusetts, USA

${ }^{2}$ Department of Medicine/Rheumatology and Clinical Immunology, Charité Universitätsmedizin and Deutsches Rheumaforschungszentrum (DRFZ), Berlin, Germany

${ }^{3}$ Leeds Institute of Rheumatic and Musculoskeletal Medicine, University of Leeds, Chapel Allerton Hospital, Leeds, UK

${ }^{4}$ Department of Rheumatology, Diakonhjemmet Hospital, Oslo, Norway

${ }^{5}$ Department of Rheumatology, Leiden University Medical Center, Leiden, The Netherlands

Correspondence to Professor Jonathan Kay, Division of Rheumatology, Department of Medicine, UMass Memorial Medical Center and University of Massachusetts Medical School, Worcester, MA 01605, USA; jonathan.kay@umassmemorial.org

Handling editor Josef S Smolen

Contributors JK drafted the response to the eLetter with advice from FCB, TD, PE and TKK. All authors have reviewed and approved the final manuscript.

Funding The authors have not declared a specific grant for this research from any funding agency in the public, commercial or not-for-profit sectors.

Competing interests JK has received research grants paid to his institution from AbbVie, Eli Lilly and Company, Genentech, Gilead Sciences, Pfizer and $U C B$, and has provided expert advice to AbbVie, Amgen, Boehringer Ingelheim, Bristol-Myers Squibb, Celgene, Celltrion Healthcare, Eli Lilly and Company, Epirus Biopharmaceuticals, Janssen Biotech, Merck Sharp \& Dohme, Myriad Genetics, Novartis Pharmaceuticals, Pfizer, Roche Laboratories, Samsung Bioepis, Sandoz and UCB. TD has received research grants or independent data monitoring committee honoraria paid to his institution from Celgene, GlaxoSmithKline, Samsung Bioepis, Roche Laboratories, Sanofi and UCB, and has provided expert advice to and/or had speaking engagements for Bristol-Myers Squibb, Celgene, GlaxoSmithKline, Merck Sharp \& Dohme, Pfizer/Hospira, Samsung Bioepis, Roche Laboratories, Sanofi and UCB. PE has received research grants paid to his institution from and has provided expert advice to AbbVie, Bristol-Myers Squibb, Eli Lilly and Company, Merck Sharp \& Dohme, Novartis, Pfizer, Samsung Bioepis, Sandoz, Roche Laboratories and UCB. TKK has received research grants paid to his institution from AbbVie, Merck Sharp \& Dohme and Pfizer/Wyeth, and has provided expert advice to and/or had speaking engagements for AbbVie, Amgen, Biogen, Celltrion Healthcare, Merck Sharp \& Dohme, Mylan NV, Orion, Pfizer, Samsung Bioepis, Sandoz, Sanofi Genzyme, Roche Laboratories and UCB. FCB has provided expert advice to and/or had speaking engagements for AbbVie, Amgen, Epirus Biopharmaceuticals, Merck Sharp \& Dohme and Pfizer.

Patient consent Not required.

Provenance and peer review Not commissioned; internally peer reviewed.

(c) Author(s) (or their employer(s)) 2020. No commercial re-use. See rights and permissions. Published by BMJ.

\section{Check for updates}

To cite Kay J, Dörner T, Emery P, et al. Ann Rheum Dis 2020;79:e44.

Received 31 December 2018

Accepted 2 January 2019

Published Online First 18 January 2019

Ann Rheum Dis 2020;79:e44. doi:10.1136/annrheumdis-2018-214994

ORCID iDs

Jonathan Kay http://orcid.org/0000-0002-8970-4260

Paul Emery http://orcid.org/0000-0002-7429-8482

\section{REFERENCES}

1 Cantini F, Benucci M. Switching from the bio-originators to biosimilar: is it premature to recommend this procedure? Ann Rheum Dis 2019;78:e23.

2 Kay J, Schoels MM, Dörner T, et al. Consensus-based recommendations for the use of biosimilars to treat rheumatological diseases. Ann Rheum Dis 2018;77:165-74.
3 Tanaka Y, Yamanaka H, Takeuchi T, et al. Safety and efficacy of CT-P13 in Japanese patients with rheumatoid arthritis in an extension phase or after switching from infliximab. Modern Rheumatology 2017;27:237-45.

4 Park W, Yoo DH, Miranda P, et al. Efficacy and safety of switching from reference infliximab to CT-P13 compared with maintenance of CT-P13 in ankylosing spondylitis: 102-week data from the PLANETAS extension study. Ann Rheum Dis 2017;76:346-54

5 Yoo DH, Prodanovic N, Jaworski J, et al. Efficacy and safety of CT-P13 (biosimilar infliximab) in patients with rheumatoid arthritis: comparison between switching from reference infliximab to CT-P13 and continuing CT-P13 in the PLANETRA extension study. Ann Rheum Dis 2017;76:355-63.

6 Smolen JS, Choe JY, Prodanovic N, et al. Safety, immunogenicity and efficacy after switching from reference infliximab to biosimilar SB2 compared with continuing reference infliximab and SB2 in patients with rheumatoid arthritis: results of a randomised, double-blind, phase III transition study. Ann Rheum Dis 2018;77:234-40

7 Emery P. Vencovský J, Sylwestrzak A, et al. Long-term efficacy and safety in patients with rheumatoid arthritis continuing on SB4 or switching from reference etanercept to SB4. Ann Rheum Dis 2017;76:1986-91.

8 Weinblatt ME, Baranauskaite A, Dokoupilova E, et al. Switching from reference adalimumab to SB5 (adalimumab biosimilar) in patients with rheumatoid arthritis: Fifty-two-week phase III randomized study results. Arthritis Rheumatol 2018;70:832-40.

9 Cohen SB, Alonso-Ruiz A, Klimiuk PA, et al. Similar efficacy, safety and immunogenicity of adalimumab biosimilar BI 695501 and Humira reference product in patients with moderately to severely active rheumatoid arthritis: results from the phase III randomised VOLTAIRE-RA equivalence study. Ann Rheum Dis 2018;77:914-21

10 Jørgensen KK, Olsen IC, Goll GL, et al. Switching from originator infliximab to biosimilar CT-P13 compared with maintained treatment with originator infliximab (NOR-SWITCH): a 52-week, randomised, double-blind, non-inferiority trial. The Lancet 2017:389:2304-16.

11 Avouac J, Moltó A, Abitbol V, et al. Systematic switch from innovator infliximab to biosimilar infliximab in inflammatory chronic diseases in daily clinical practice: the experience of Cochin University Hospital, Paris, France. Semin Arthritis Rheum 2018:47:741-8.

12 Germain V, Scherlinger M, Barnetche T, et al. Long-term follow-up after switching from originator infliximab to its biosimilar CT-P13: the weight of nocebo effect. Ann Rheum Dis 2018:annrheumdis-2018-214374.

13 Benucci M, Gobbi FL, Bandinelli F, et al. Safety, efficacy and immunogenicity of switching from innovator to biosimilar infliximab in patients with spondyloarthritis: a 6-month real-life observational study. Immunol Res 2017:65:419-22.

14 Nikiphorou E, Kautiainen H, Hannonen P, et al. Clinical effectiveness of CT-P13 (infliximab biosimilar) used as a switch from Remicade (infliximab) in patients with established rheumatic disease. Report of clinical experience based on prospective observational data. Expert Opin Biol Ther 2015;15:1677-83.

15 Vergara-Dangond C, Sáez Belló M, Climente Martí M, et al. Effectiveness and safety of switching from innovator infliximab to biosimilar CT-P13 in inflammatory rheumatic diseases: a real-world case study. Drugs $R$ D 2017;17:481-5.

16 Glintborg B, Sørensen IJ, Loft AG, et al. A nationwide non-medical switch from originator infliximab to biosimilar CT-P13 in 802 patients with inflammatory arthritis: 1-year clinical outcomes from the DANBIO registry. Ann Rheum Dis 2017;76:1426-31.

17 Glintborg B, Loft AG, Omerovic E, et al. To switch or not to switch: results of a nationwide guideline of mandatory switching from originator to biosimilar etanercept. one-year treatment outcomes in 2061 patients with inflammatory arthritis from the DANBIO registry. Ann Rheum Dis 2019:78:192-200.

18 Griffiths CEM, Thaçi D, Gerdes S, et al. The EGALITY study: a confirmatory, randomized, double-blind study comparing the efficacy, safety and immunogenicity of GP2015, a proposed etanercept biosimilar, vs. the originator product in patients with moderate-to-severe chronic plaque-type psoriasis. Br J Dermatol 2017:176:928-38.

19 Schneider CK. Biosimilars in rheumatology: the wind of change. Ann Rheum Dis 2013;72:315-8.

20 Schiestl M, Stangler T, Torella C, et al. Acceptable changes in quality attributes of glycosylated biopharmaceuticals. Nat Biotechnol 2011;29:310-2.

$21 \mathrm{Kim}$ S, Song J, Park S, et al. Drifts in ADCC-related quality attributes of Herceptin $®$ : impact on development of a trastuzumab biosimilar. MAbs 2017;9:704-14.

22 US Food \& Drug Administration. FDA briefing document: Arthritis Advisory Committee meeting, February 09, 2016. BLA 125544: CT-P13, a proposed biosimilar to Remicade $®$ (infliximab), Celltrion. Washington DC: Department of Health \& Human Services, 2016: 1-73. https://www.fda.gov/downloads/.../UCM484859.pdf. 